\title{
CUSTOMERS' BELIEFS BEHIND BUSINESS-TO-CONSUMER ELECTRONIC COMMERCE
}

\author{
Nena Lim \\ Commerce Department \\ University of Queensland \\ Brisbane, Australia \\ Email: nlim@commerce.uq.edu.au
}

\begin{abstract}
With the rising importance of electronic commence, it is important for researchers and company executives to understand customers' beliefs behind online shopping behaviour. This proposed study extends the technology acceptance model (TAM) to test the influence of experience, self-efficacy, perceived risk, and social influence on customers' acceptance of the business-to-consumer (b2c) e-commerce.
\end{abstract}

\section{Keywords}

Electronic Commerce, Technology Acceptance Model, System Use, Adoption, Perceived Risk, Experience, User Acceptance, Online Buying Behaviour

\section{INTRODUCTION}

Based on the technology acceptance model (TAM), the present study examines the following research question: In what ways do experience (Davis et al., 1989; Karahanna et al., 1999; Taylor \& Todd, 1995), self-efficacy (Bandura 1977; 1982), perceived risk (Cox \& Rich, 1964; Jarvenpaa \& Todd, 1996), and social influence (Salancik \& Pfeffer, 1978; Fulk et al., 1990) affect customers' acceptance of the business-to-consumer electronic commerce? Acceptance of business-to-consumer e-commerce refers to when a customer prefers to buy online instead of buying through other marketing channels, such as store-based retailing and telephone shopping.

According to the Electronic Commerce Association, electronic commerce (e-commerce) is "any form of business or administrative transaction or information exchange that is executed using any information and communications technology" (Till, 1998, p. 9). With the rising importance of e-commerce, some people expect it to bring sociodemographic changes as well as business advantages. For business people, e-commerce is a unique two-way communication approach to a direct marketing channel (Jarvenpaa \& Todd, 1996). Drucker (1999) suggests that e-commerce might even lead to an information revolution.

In monetary terms, Beer (2000) estimates that Australian businesses will spend over A $\$ 2.64$ billion on Web technology in 2000. ActivMeida (1999) reports that US $\$ 95$ billion revenues were generated from global ecommerce in 1999. Revenue is expected to exceed US $\$ 220$ billion in 2000 (ActivMedia, 1999), and reach US $\$ 6.9$ trillion by 2004 (Nua, 2000).

A common approach is to classify e-commerce in two ways: business-to-business (b2b) and business-toconsumer (b2c). B2b e-commerce refers to paperless exchange of business information over the Internet. It involves activities such as electronic data interchange (EDI) and electronic funds transfer (EFT). B2c ecommerce involves companies selling goods or services to customers online. This study focuses on b2c ecommerce. It uses the terms b2c e-commerce and online shopping interchangeably.

\section{BUSINESS-TO-CONSUMER (B2C) ELECTRONIC COMMERCE}

B2c e-commerce gets much publicity through companies, such as Yahoo.com and Amazon.com (MIS Australia, 2000). Studies show that customers purchase online because it is convenient, without sales pressure, and saves time (GVU, 1999; Henderson et al., 1998). A spate of studies by various consulting companies indicate that online shopping has a huge, relatively untapped market. According to a Boston Consulting Group report on b2c e-commerce, North-American retailers generated US $\$ 33.1$ billion revenues in 1999 . The 2000 revenue figure is expected to jump to US $\$ 61.1$ billion (Boston Consulting Group, 2000). European retailers obtained US $\$ 2.8$ billion from online sales in 1999 (Conlin, 2000). They are expected to generate US $\$ 8.9$ billion by the end of year 2000 (Boston Consulting Group, 2000). Regarding Australia, Horey (1999) estimated that the online revenue was A $\$ 920 \mathrm{~m}$ in 1999 . The number of Australian online shoppers is expected to reach 3.8 million by the end of 2000 (Consult Pty., 2000).

Although increasing results seem to suggest that online shopping is growing rapidly, predictions on b2c business could be optimistic (Switzer, 2000). For example, the 1999 North-American online revenue figure (US $\$ 33.1$ billion) is still relatively small, because it represents only 1.4 percent of all retail sales (Boston Consulting Group, 2000). Charlton et al. (1999) found that the general public in the United Kingdom exhibits little interest in e-commerce. Moreover, customers often browse items online but with no intention to buy (GVU, 1999). In their study on gender and Internet shopping, Fram \& Grady (1997) suggest that women only have moderate 
interest in online shopping. In addition, 65 to 75 percent of online shoppers in two different studies abandoned their purchases before the purchases were completed (Boston Consulting Group, 2000; Vu et al., 1999).

In short, on the one hand, growing studies (e.g., ActivMedia, 1999; Boston Consulting Group, 2000; Nua Ltd., 2000 ) suggest that b2c business will grow substantially. On the other hand, evidence shows that many customers may still not want to purchase online (Boston Consulting Group, 2000; Charlton et al., 1999; GVU, 1999; Vu et al., 1999). Because of the increasing financial investment by organisations (Beer, 2000) and potentially large profits from b2c e-commerce (ActivMedia, 1999; Horey, 1999; Boston Consulting Group, 2000), it is important for researchers and company executives to understand more about online shopping behaviour. With the objective to enhance the acceptance of online shopping, this study examines the beliefs behind customers' behaviour.

\section{TECHNOLOGY ACCEPTANCE MODEL (TAM)}

Evaluation of the success of information technology or information systems has been an important topic for researchers and practitioners (Delone \& McLean, 1992). Among the various evaluation criteria proposed by researchers, user acceptance of a new technology or system is considered to be a vital and useful criterion. Based on the theory of reasoned action (Fishbein \& Ajzen, 1975; Ajzen \& Fishbein, 1980), the technology acceptance model (TAM) focuses on two perceptions, perceived usefulness and perceived ease of use, to predict users' acceptance of new technology (Davis, 1989; Davis et al., 1989).

Because the TAM is parsimonious and well developed (Davis \& Venkatesh, 1996), many researchers have adopted this model to assess users' acceptance of different technologies, such as microcomputers (Igbaria et al., 1995), word processing systems (Adams et al., 1992; Davis \& Venkatesh, 1996), spreadsheet systems (Adams et al., 1992; Davis \& Venkatesh, 1996; Hendrickson et al., 1993; Mathieson, 1991), and database systems (Hendrickson et al., 1993).

Over the years, many researchers have added constructs to the TAM to try to enhance its predictive power. Some studies elaborated external variables that affect perceived ease of use and perceived usefulness in TAM to better understand the motivation behind users' behaviour. For example, Gefen \& Straub (1997) studied the impact of gender on usage of email. Gefen \& Keil (1998) focused on the effect of perceived developer responsiveness on perceived ease of use and perceived usefulness. Karahanna \& Straub (1999) examined the effect of four types of external variables, namely, social presence, social influence, availability of user training and support, and perceived accessibility, on an email system.

\section{STUDIES ON THE WORLD WIDE WEB/ELECTRONIC COMMERCE}

Literature indicates that many existing studies on the World Wide Web (WWW/Web) or e-commerce pertain to human-computer interaction ( $\mathrm{HCl}$. These $\mathrm{HCI}$ studies focus on the physical features, such as web interface design and the navigation pattern of surfers (e.g., Grose et al., 1998; McDonald \& Stevenson, 1998). Results of these $\mathrm{HCI}$ studies give information, such as how to distinguish a good Web page from a bad one. Unfortunately, they do not tell company executives why customers buy or do not buy online.

Instead of focusing on $\mathrm{HCI}$ issues, some studies examine the acceptance of the Web technology by focusing on the beliefs and motivations of customers (Jarvenpaa \& Todd, 1996; Agarwal \& Prasad, 1997; Morris \& Dillon, 1997; Fram \& Grady, 1997; Fenech, 1998; Agarwal \& Prasad, 1998; Parthasarathy \& Bhattacherjee, 1998). Most Web-related studies adopted the TAM or the innovation diffusion theory as the basic research model. Innovation diffusion theory (Rogers, 1983; Moore \& Benbasat, 1991) is similar to the TAM. This theory postulates that researchers can predict innovation diffusion by examining users' belief over various characteristics of the innovation. The eight perceived characteristics of innovations reported by Moore \& Benbasat (1991) are voluntariness, relative advantage, image, compatibility, complexity, trialability, visibility, and result demonstrability. Table 1 is a summary of these Web-related prior studies. 


\begin{tabular}{|c|c|c|c|c|c|}
\hline Year & Author & Focus of study & Methodology & Sample & $\begin{array}{l}\text { Theory }{ }^{+} \text {, additional } \\
\text { variables }\end{array}$ \\
\hline 1996 & $\begin{array}{l}\text { Jarvenpaa \& } \\
\text { Todd }\end{array}$ & $\begin{array}{l}\text { electronic shopping } \\
\text { on WWW }\end{array}$ & $\begin{array}{l}\text { open-ended } \\
\text { survey; focus } \\
\text { group }\end{array}$ & 220 shoppers & Nil \\
\hline 1997 & $\begin{array}{l}\text { Agarwal \& } \\
\text { Prasad }\end{array}$ & WWW for learning & experiment & $\begin{array}{l}73 \quad \mathrm{MBA} \\
\text { students }\end{array}$ & $\begin{array}{l}\text { Innovation } \\
\text { theory }+ \\
\text { voluntariness }\end{array}$ \\
\hline 1997 & Fram \& Grady & $\begin{array}{l}\text { cyber shopping } \\
\text { pattern }\end{array}$ & $\begin{array}{l}\text { field study } \\
\text { (survey on the } \\
\text { Web) }\end{array}$ & 254 women & Nil \\
\hline 1997 & $\begin{array}{l}\text { Morris } \\
\text { Dillon }\end{array}$ & $\begin{array}{ll}\text { Information } \\
\text { searching using } \\
\text { Netscape } \\
\end{array}$ & $\begin{array}{ll}\text { field } & \text { study } \\
\text { (survey) } & \end{array}$ & 76 students & $\begin{array}{l}\text { Technology acceptance } \\
\text { model (TAM) }\end{array}$ \\
\hline 1998 & $\begin{array}{l}\text { Agarwal } \\
\text { Prasad }\end{array}$ & $\begin{array}{l}\text { WWW information } \\
\text { services on the } \\
\text { Internet }\end{array}$ & $\begin{array}{ll}\text { field } & \text { study } \\
\text { (survey) } & \end{array}$ & $\begin{array}{l}175 \text { part-time } \\
\text { MBA } \\
\text { students }\end{array}$ & $\begin{array}{ll}\text { TAM }+ & \text { personal } \\
\text { innovativeness } & \end{array}$ \\
\hline 1998 & Fenech & WWW in general & survey & 150 students & TAM + self-efficacy \\
\hline 1998 & $\begin{array}{l}\text { Henderson } \\
\text { al. }\end{array}$ & $\begin{array}{l}\text { electronic } \\
\text { supermarket }\end{array}$ & $\begin{array}{l}\text { experiment } \\
\text { (followed by } \\
\text { focus groups); } \\
\text { survey }\end{array}$ & $\begin{array}{l}57 \text { families; } \\
64 \text { users }\end{array}$ & $\begin{array}{l}\text { TAM + enjoyment }+ \text { peer- } \\
\text { group norms }+ \text { usability }+ \\
\text { experience }+ \text { individual- } \\
\text { situational factors }\end{array}$ \\
\hline 1998 & $\begin{array}{l}\text { Parthasarathy } \\
\& \\
\text { Bhattacherjee }\end{array}$ & online services & field survey & $\begin{array}{l}145 \\
\text { subscribers }\end{array}$ & $\begin{array}{l}\text { Innovation diffusion } \\
\text { theory + external influence } \\
+ \text { interpersonal influence + } \\
\text { network externality } \\
\end{array}$ \\
\hline 1999 & $\begin{array}{l}\text { Korgaonkar \& } \\
\text { Wolin }\end{array}$ & WWW in general & $\begin{array}{l}\text { focus } \\
\text { survey }\end{array}$ & $\begin{array}{lr}6 & \text { focus } \\
\text { groups; } \quad 401 \\
\text { consumers } \\
\end{array}$ & $\begin{array}{l}\text { Media uses and } \\
\text { gratification theory }\end{array}$ \\
\hline
\end{tabular}

Table 1 Summary of studies on acceptance of the Web/electronic commerce

\section{Problems of Existing Web-related Studies}

A few problems in the following aspects can be observed from Table 1:

- focus of study

- theory testing

- modification of the technology acceptance model

First, except for Henderson et al. (1998), all the Web-related studies in Table 1 examine users' overall impression of the Internet or the Web. Unfortunately, because of the broad nature of the Internet and the Web, results of these studies are not especially useful for practitioners.

Second, some studies in Table 1 are open-ended survey type studies. Such studies are exploratory in nature, and do not contain any theory or research model (Fram \& Grady, 1997; Jarvenpaa \& Todd, 1996). For instance, although Jarvenpaa \& Todd (1996) classify customers' responses into four categories based on studies in storebased retailing and direct marketing, their results simply represent a list of concerns of the customers regarding online shopping. Their study suggests that experience, and perceived risk may play important roles in predicting Web acceptance.

Third, for those Web-related studies that specified research models, most applied the simple TAM approach or innovation diffusion theory (e.g., Agarwal \& Prasad, 1997; Morris \& Dillon, 1997). Nonetheless, because of the difference between ordinary information systems and e-commerce, a simple TAM or innovation diffusion approach is unlikely to predict acceptance accurately. For instance, the scope of e-commerce is much wider than ordinary information systems as it extends across numerous people and organisations. Moreover, e-commerce carries financial consequences for the users. Therefore, from the customers' or users' viewpoints, risk becomes a vital factor. As more than 50 percent of customers abandon purchases before purchases are completed (Boston Consulting Group, 2000; Vu et al., 1999), it is an interesting question to find out whether self-efficacy of customers contributes to this behaviour.

To tackle the problems of the existing studies, this study adds potentially important constructs to the TAM, and examines the effect of these constructs. Moreover, this study focuses on certain types of goods and services in online shopping. Fram \& Grady (1997) found that women often purchase software, books, and music online. 
Across different countries, GVU (1999) also reported that hardware, software, books, music, and travel are the five most common items that customers intend to buy when they browse the Web. To enhance the predictive power of the proposed model, this research focuses only on online customers' purchasing behaviour in relation to these five items. This study does not distinguish between multichannel retailers, such as airlines, and online-only retailers, such as e-store.com.au and dstore.com.au.

\section{CONCEPTUAL MODEL}

This research examines the factors that motivate acceptance of online shopping from the customers' viewpoint. Figure 1 describes the research model for this study. Both Agarwal \& Prasad (1997) and Agarwal \& Prasad (1998) reported an adjusted coefficient of determination that is below 0.5. It is expected that the constructs proposed in the model will be able to explain a larger proportion of variance in online shopping behaviour than existing studies.

To focus on the subjective perceptions from customers' viewpoints, however, this study does not consider objective factors that may affect online shopping, such as speed of transmission lines, quality of products, and prices of products. The following sections describe the potentially important constructs and the proposed hypotheses.

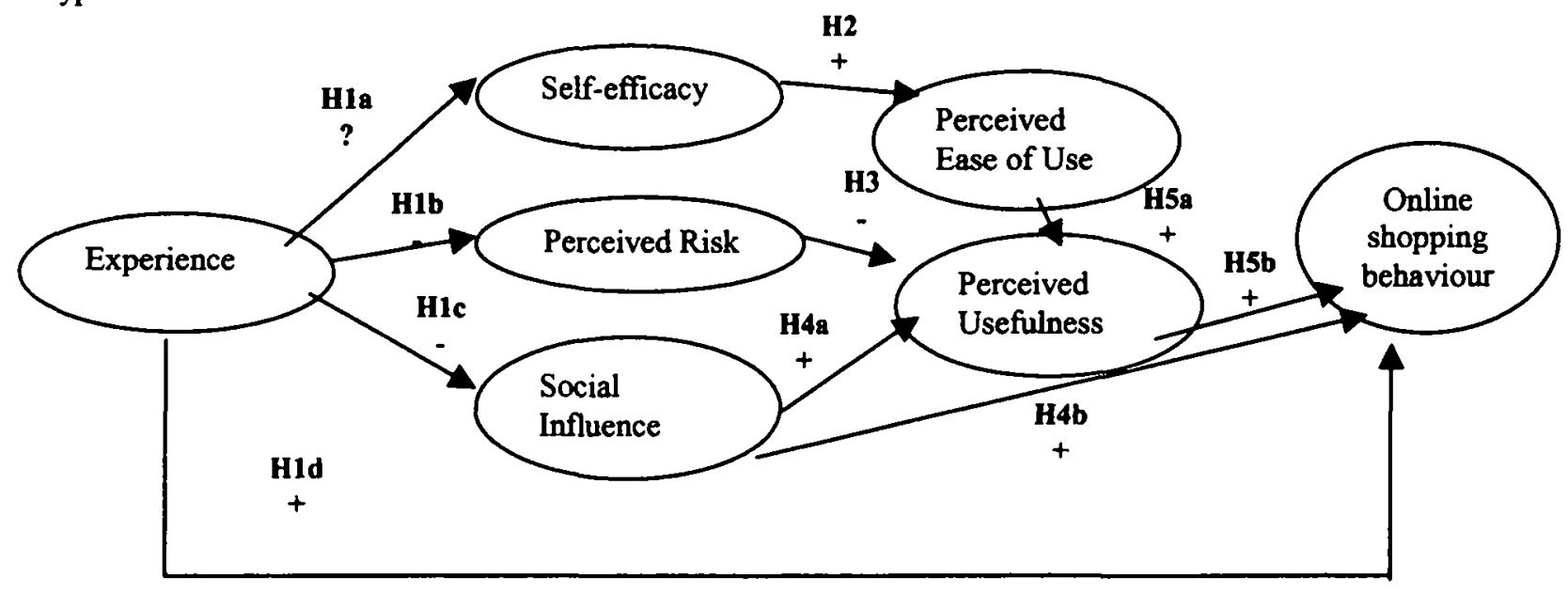

Figure 1 B2C e-commerce adoption model

\section{Experience}

Previous studies on TAM have shown that experience potentially influences users' acceptance of new technology (Adams et al., 1992; Chau \& Hui, 1998; Davis, et al., 1989; Igbaria et al., 1995; Karahanna et al., 1999; Szajna, 1996; Taylor \& Todd, 1995; Thompson et al., 1994). Ratnasingham (1999) found that companies are more secure when they trade with existing EDI partners. In a study regarding telephone shopping, Cox \& Rich (1964) also found that prior shopping experience can reduce uncertainty. Thus, it is likely that customers will feel more comfortable buying online if they have good online buying experience. Experience was reported as vital in two of the studies in Table 1 (Henderson et al., 1998; Jarvenpaa \& Todd, 1996).

This study defines experience as online shopping experience. To make the results more meaningful, this study focuses only on prior experience with b2c e-commerce. It is not concerned with general computer experience. This study measures experience in three ways: (a) the number of times a customer tried to buy goods or services online; (b) the number of times a customer bought goods or services online; and (c) the number of times a customer felt satisfied with completed online shopping.

It is expected that, with more practice, a user will learn new skills and possibly increase his or her self-efficacy. Compeau \& Higgins (1995a) argue that previous experience of technology helps to enhance users' self-efficacy in using the technology. On the other hand, Venkatesh \& Davis (1996) report that self-efficacy does not change over time with experience. In view of this contradictory result, the present study does not specify the direction of the association:

- Hla: Experience is associated with self-efficacy.

With prior online shopping experience, this study postulates that perceived risk of customers over b2c ecommerce will be reduced. Referring to EDI, Ratnasingham (1999) indicates that organisations get a higher level of security if they have previous experience with the business parties. Similarly, if customers buy from the same 
vendors, perceived risk will be reduced.

- H1b: Experience is negatively associated with perceived risk.

Karahanna et al. (1999) and Thompson et al. (1994) found that social influence had a greater impact on inexperienced users than experienced users. With experience, users may be better able to form their opinions on the new technology instead of relying on or being affected by the comments of other people. Thus, the following hypothesis is proposed:

- Hlc: Experience is negatively associated with social influence.

Hubona \& Geitz (1997) conclude that external variables do not always affect usage behaviour through mediating belief constructs. Their results show that the direct linkage between experience and usage is significant. Moreover, Thompson et al. (1994) report that experience has a direct effect on the behaviour of personal computer usage. The results also indicate that the indirect effect of experience through users' beliefs is much smaller than the direct effect. Therefore, this study hypothesises that:

- Hld: Experience is positively and directly associated with online shopping behaviour.

\section{Self-Efficacy}

The concept of self-efficacy originated from Bandura's social cognitive theory (Bandura, 1977; 1982). Selfefficacy is about perception of ability. It refers to how confident users are in doing certain tasks, such as using new technologies. In this study, self-efficacy is defined as an individual's perceived ability to buy goods or services on the Web.

Pooling data on different technologies from different organisations, Compeau \& Higgins (1995b) and Compeau et al. (1999) found that computer self-efficacy has an important impact on users' affect, anxiety, and usage. Moreover, Compeau \& Higgins (1995a) reported that self-efficacy affects computing performance, whereas Davis et al. (1989) and Compeau et al. (1999) showed that self-efficacy perceptions affect the perceived ease of use of users.

In spite of the importance of self-efficacy, only Fenech (1998) has examined the impact of self-efficacy in the studies shown in Table 1. Fenech (1998) reported that the predictability of TAM was greatly improved by the addition of computer self-efficacy because adjusted goodness-of-fit index jumped from 0.556 to 0.89 . Venkatesh \& Davis (1996) suggest that users with a higher level self-efficacy tend to perceive new technology as easier to use. Users with high self-efficacy are more willing to learn a new technology. Therefore this study hypothesises that:

- H2: Self-efficacy is positively associated with perceived ease of use.

\section{Perceived Risk}

Researchers in psychology have widely studied risk theory, especially in relation to gambling behaviour (e.g., Pollatsek \& Tversky, 1970; Jia et al., 1999). Traditionally, developers of information systems do not pay much attention to security or risk (Straub \& Welke, 1998). Security and risk issues have always been described as one of the critical factors, however, for e-commerce success (Arnum, 1995; Fram \& Grady, 1997; Rebel \& Koenig, 1999; Till, 1998). For instance, Fram \& Grady (1997) report that online customers are concerned about credit card fraud. They normally purchase only products with low purchasing risk.

The fragility of the Web and e-commerce was evidenced in February 2000. In that incident, traffic to websites such as Yahoo, Amazon, CNN, and eBay were jammed with junk messages (Richtel \& Robinson, 2000). A telephone survey conducted after the incident indicates that 70 percent of online shoppers were worried about the attack. Thirty percent of the respondents said that they would be less likely to buy online (Schwartz, 2000).

New technologies and protocols, such as digital signatures, encryption (Arnum, 1995), and wireless application protocol (Zampetakis, 2000), are used to improve Internet security. Moreover, online companies obtain a Webtrust seal of assurance to enhance customers' confidence in online shopping. A Webtrust seal indicates that a company has fulfilled certain security principles and criteria as specified by professional accounting bodies (ICAA, 1999).

In spite of the calls for better security, a study done by the Georgia Institute of Technology indicates that security is not the most important determinant for online shopping (GVU, 1999). Moreover, although Jarvenpaa \& Todd (1996) found that risk is an important factor in electronic shopping, their results also indicate that consumers consider product perceptions, shopping experience, and customer service as more important. An objective of this study is to examine the extent to which perceived risk is a deterrent to online shopping.

In the marketing literature, Cox \& Rich (1964) argue that customers who use telephone shopping perceive risk because they cannot personally inspect the products or compare the quality, size, or style of products. Customers may also perceive risk because time may be lost or frustration may result where the purchases are unsuccessful. 
Following Cox \& Rich (1964), this study defines perceived risk as "the nature and amount of risk perceived by a consumer in contemplating a particular purchase action" (p. 33). In their study of mail-order shopping, Simpson \& Lakner (1993) identify four types of perceived risk, namely, economic, performance-related, physical, and social/psychological. Based on Simpson \& Lakner (1993), Jarvenpaa \& Todd (1996) identify the following five types of risk in online shopping:

- Economic risk: The risk of monetary loss arising from online shopping. It is a result of the unreliability of vendors.

- Social risk: Social risk involves acceptance of the shopping behaviour by other society members, such as family, and friends.

- Performance risk: Performance risk is concerned about whether the purchased goods or services are able to meet customers' expectations.

- Personal risk: The possibility of any harm to the customers because of the purchase behaviour. For example, customers may suffer because credit card information is compromised.

- Privacy risk: Customers suffer from privacy risk if they lose their privacy. This may be a result of the fact that information is collected about the customers during the shopping process.

Jarvenpaa \& Todd (1996)'s results indicate that personal risk and performance risk are more important than other types of risk. This study adapts Jarvenpaa \& Todd's classification and proposes four types of perceived risk regarding b2c e-commerce. The privacy risk in Jarvenpaa \& Todd (1996) is combined with the personal risk in this study because these two types of risk are similar.

In relation to b2c e-commerce, customers find online shopping useful if they can get the shopping done fast or the information provided on the Web can help customers make purchasing decisions. If customers perceive high levels of risk in online shopping, it is likely that they will find b2c e-commerce less useful. However, if customers are willing to continue to purchase online, it implicitly reflects that customers find online shopping useful. Therefore, this study hypothesises that:

- H3: Perceived risk is negatively associated with perceived usefulness.

\section{Social Influence}

The idea of social influence originated from social psychology (Salancik \& Pfeffer, 1978; Fulk et al., 1990). In some cases, researchers used different terminology to describe social influence. For example, the theory of reasoned action (Fishbein \& Ajzen, 1975; Ajzen \& Fishbein, 1980; Karahanna et al., 1999) used the term "subjective norm", whereas Chau \& Hui (1998) used "opinion leader."

Social influence in this study refers to the influence of colleagues, friends, and relatives on customers. Kelman (1961) identifies three stages in social influence: compliance, identification, and internalization. At the compliance stage, a person is under social influence because he or she simply wants to get a favourable reaction from others. At the identification stage, a person actually sees some advantages in the social influence, although the main motivation is still to meet others' expectations. At the final stage, a person internalises other people's values or opinions.

This study includes social influence because recent studies suggest that this factor has an impact on new technology usage (Gefen \& Straub, 1997; Henderson et al., 1998; Jasperson et al., 1999; Venkatesh \& Morris, 2000). Jasperson et al. (1999) found that social influence could lead to three types of responses (conformance, imitation, and mutual discovery) in new technology usage. So far, TAM researchers have different opinions on the usefulness of social influence. Davis (1989), Adams et al. (1992), and Szajna (1996) did not examine this construct in their research. Most studies that consider this construct report that it is significant (Karahanna \& Straub, 1999; Venkatesh \& Morris, 2000; Agarwal, \& Prasad, 1997). Parthasarathy \& Bhattacherjee (1998) found that social influence is more important than external influences such as advertisements. Nonetheless, some studies found social influence to be insignificant (e.g., Davis et al., 1989; Mathieson, 1991).

Schmitz \& Fulk (1991) and Karahanna \& Straub (1999) found that social influence has a significant impact on behavioural intention through perceived usefulness. However, the theory of reasoned action posits that social influence has a direct effect on behavioural intention (Fishbein \& Ajzen, 1975; Ajzen \& Fishbein, 1980). Karahanna et al. (1999) also report that potential adopters' intention to adopt new technology was solely affected by social influence. Their model indicates a direct relationship between social influence and behavioural intention. Hence, this study tests the following two hypotheses:

- H4a: Social influence is positively associated with perceived usefulness.

- H4b: Social influence is positively and directly associated with online shopping behaviour. 


\section{Perceived Ease of Use and Perceived Usefulness}

Prior studies found that perceived ease of use only has an indirect effect on usage through perceived usefulness (Gefen \& Keil, 1998; Karahanna \& Straub, 1999). Moreover, research to date consistently shows that perceived usefulness is a significant predictor of system usage (Davis, 1989; Davis et al., 1989; Karahanna \& Straub, 1999). Therefore, this study examines the following two hypotheses:

- H5a: Perceived ease of use is positively associated with perceived usefulness.

- H5b: Perceived usefulness is positively associated with online shopping behaviour.

\section{CONCLUSION}

This proposed study reconstructs the boundary of TAM in the current Web-dominant situation by adding experience, self-efficacy, perceived risk, and social influence. Moreover, this study can help businesses adjust their e-commerce strategies. For instance, businesses can learn from the results, and decide whether it is worthwhile to spend more money on upgrading security over the Web. This in turn will affect the future development of security of the Web. Moreover, if the results support the importance of experience on online shopping, this outcome should motivate companies to spend more effort, such as giving special discounts, to attract new customers. If social influence is found to be significant, managers may need to think of ways to create a positive social influence over customers.

The research methodology of this study is survey. It is assumed that this model is in equilibrium. Therefore, it is appropriate to examine the associations among constructs in a cross-sectional manner. The target participants are university students and employees of organisations involved in e-commerce. These two groups of people are believed to represent an important portion of the e-commerce customers because of their easy access to the Internet. The next step of this research is to prepare survey instruments. Existing instruments of perceived ease of use, perceived usefulness, and self-efficacy will be adopted (Davis, 1989; Compeau \& Higgins, 1995b), whereas new instruments will be developed for the other constructs. A pilot study will be performed to confirm the validities and reliability of the instruments before actual data collection.

\section{REFERENCES}

ActivMedia Research LLC(1999) Real Numbers Behind 'Net Profits', URL http://research.activmedia.com/reports/m99exec/m99execsummary.pdf

Adams, D.A., Nelson, R.R. \& Todd, P.A. (1992) "Perceived usefulness, ease of use and usage of information technology: A replication" MIS Quarterly, 16(2), 227-247.

Agarwal, R., \& Prasad, J. (1997) "The role of innovation characteristics and perceived voluntariness in the acceptance of information technologies" Decision Sciences, 28(3), 557-582.

Agarwal, R., \& Prasad, J. (1998) "A conceptual and operational definition of personal innovativeness in the domain of information technology" Information Systems Research, 9(2), 204-215.

Ajzen, I., \& Fishbein, M. (1980) Understanding Attitudes and Predicting Social Behaviour, Prentice Hall: Enlewood Cliffs, NJ.

Arnum, E. (1995) "Doing business on the Internet-A question of balance" Business Communications Review, 25(8), 35-37.

Bandura, A. (1977) "Self-Efficacy: Toward a unifying theory of behavioural change" Psychological Review, 84(2), 191-215.

Bandura, A. (1982) "Self-Efficacy mechanism in human agency" American Psychologist, 37(2), 122-147.

Beer, S. (2000) "E-commerce to double internet spending" The Australian Financial Review, 4 April, 45.

Boston Consulting Group (2000) The State of Online Retailing 3.0, Shop.org, URL http://www.shop.org/research/default.htm

Charlton, C., Gittings, C., Leng, P., Little, J., \& Neilson, I. (1999) "Bring the internet to the community" Interacting with Computers, 12, 51-61.

Chau, P.Y.K., \& Hui, K.L. (1998) "Identifying early adopters of new IT products: A case of Windows 95" Information \& Management, 33, 225-230.

Compeau, D.R., \& Higgins, C.A. (1995a) "Application of social cognitive theory to training for computer skills" Information Systems Research, 6(2), 118-143.

Compeau, D.R., \& Higgins, C.A. (1995b) "Computer self-efficacy - Development of a measure and initial test" MIS Quarterly, 19(2), 189-211.

Compeau, D., Higgins, C.A., \& Huff, S. (1999) "Social cognitive theory and individual reactions to computing technology: A longitudinal study", MIS Quarterly 23(2), 145-158.

Conlin, R. (2000) "European e-commerce poised for boom" E-Commerce Times, March 28. URL http://www.ecommercetimes.com/news/articles2000/000328-7.shtml 
Consult Pty Ltd. (2000) Australian Online Shopping Report, July - December 1999, URL http://www.consult.com.au/index.html

Cox, D.F., \& Rich, S.U. (1964) 'Perceived risk and consumer decision making-The case of telephone shopping" Journal of Marketing Research, 1(4), 32-39.

Davis, F.D. (1989) "Perceived usefulness, perceived ease of use, and user acceptance of information technology" MIS Quarterly, 13(3), 319-339.

Davis, F.D., Bagozzi, R.P., \& Warshaw, P.R. (1989) "User acceptance of computer technology: A comparison of two theoretical models" Management Science, 35(8), 982-1003.

Davis, F.D., \& Venkatesh, V. (1996) "A critical assessment of potential measurement biases in the technology acceptance model: Three experiments" International Journal of Human-Computer Studies, 45(1), 19-45.

Delone, W.H., \& McLean, E.R. (1992) "Information systems success: The quest for the dependent variables" Information Systems Research, 3(1), 60-95.

Drucker, P.F. (1999 Oct.) "Beyond the information revolution" Atlantic Monthly, 47-57.

Fenech, T. (1998) "Using perceived ease of use and perceived usefulness to predict acceptance of the World Wide Web" Computer Networks and ISDN Systems, 30, 629-630.

Fishbein, M., \& Ajzen, I. (1975) Belief, Attitude, Intention and Behaviour: An Introduction to Theory and Research, Addison-Wesley, Boston, M.A.

Fram, E.H., \& Grady, D.B. (1997) "Internet shoppers: Is there a surfer gender gap?" Direct Marketing, 59(9), 46-50.

Fulk, J., Schmitz, J, \& Steinfield, C.W. (1990) "A social influence model of technology use". in J.Fulk and C.W. Steinfield (eds.) Organisations and Communication Technology, Newbury Park, CA: Sage Publications, $117-140$.

Gefen, D., \& Keil, M. (1998) "The impact of developer responsiveness on perceptions of usefulness and ease of use: An extension of the technology acceptance model" DATA BASE for Advances in Information Systems, 29(2), 35-49.

Gefen, D., \& Straub, D.W. (1997) "Gender differences in the perception and use of e-mail: An extension to the technology acceptance model" MIS Quarterly, 21(4), 389-400.

Grose, E., Forsythe, C., \& Ratner, J. (1998) "Using web and traditional style gudies to design web interfaces". in C. Forsythe, E. Grose, \& J. Ratner (eds.) Human Factors and Web Development, Lawrence Erlbaum Associates: New Jersey, 121-136.

GVU (Graphic, Visualization, \& Usability Center). (1999) GVU's Tenth World Wide Web User Survey. Georgia Institute of Technology, Atlanta, GA, USA. URL http://www.gvu.gatech.edu/gvu/user_surveys/survey-1998-10/tenthreport.html

Henderson, R., Rickwood, D., \& Roberts, P. (1998) "The beta test of an electronic supermarket" Interacting with Computers, 10, 385-399.

Hendrickson, A.R., Massey, P.D., \& Cronan, T.P. (1993) "On the test-retest reliability of perceived usefulness and perceived ease of use scales" MIS Quarterly, 17(2), 227-230.

Horey, J. (1999 Nov. 30) "Well, I'll be - it was B2C" The Australian, 8.

Hubona, G.S., \& Geitz, S. (1997) "External variables, beliefs, attitudes and information technology usage behaviour" In Proceedings of the 32nd Hawaii International Conference on System Sciences.

Igbaria, M., Guimaraes, T., \& Davis, G (1995) "Testing the determinants of micro-computer usage via a structured equation model" Journal of Management Information Systems, 11(4), 87-114.

ICAA (Institute of Chartered Accountants in Australia). (1999) Assurance for Business-to-Consumer Electronic Commerce. URL http://www.icaa.org.au/ICAA/assurance/CentreSet.htm

Jarvenpaa, S.L., \& Todd, P.A. (1996) "Consumer reactions to electronic shopping on the World Wide Web" International Journal of Electronic Commerce, 1(2), 59-88.

Jasperson, 'J(S)., Sambamurthy, V., \& Zmud, R.W. (1999) "Social influence and individual IT use: Unravelling the pathways of appropriation moves" Proceedings of the Twentieth International Conference on Information Systems, Prabuddha De, \& Janice I. DeGross (eds.). Charlotte, North Carolina, 113-118.

Jia, J.M., Dyer, J.S., \& Butler, J.C. (1999) "Measures of perceived risk" Management Science, 45(4), 519-532.

Karahanna, E., \& Straub, D.W. (1999) "The psychological origins of perceived usefulness and ease-of-use" Information \& Management, 35(4), 237-250.

Karahanna, E., Straub, D.W., \& Chervany, N.L. (1999) "Information technology adoption across time: A crosssectional comparison of pre-adoption and post-adoption beliefs" MIS Quarterly, 23(2), 183-213.

Kelman, H.C. (1961) "Process of opinion change" Public Opinion Quarterly, 25, 57-78.

Korgaonkar, P.K., \& Wolin, L.D. (1999) "A multivariate analysis of Web usage" Journal of Advertising Research, 39(2), 53-68.

Mathieson, K. (1991) "Predicting user intentions: Comparing the technology acceptance model with the theory of planned behaviour" Information Systems Research, 2(3), 173-191. 
McDonald, S., \& Stevenson, R.J. (1998) "Navigation in hyperspace: An evaluation of the effects of navigational tools and subject matter expertise on browsing and information retrieval in hypertext" Interacting with Computers, 10, 129-142.

MIS Australia. (2000) "B2B booms" March, 88.

Moore, G.C., \& Benbasat, I. (1991) "Development of an instrument to measure the perceptions of adopting an information technology innovation" Information Systems Research, 2(3), 192-222.

Morris, M.G., \& Dillon, A. (1997) "How user perceptions influence software use" IEEE Software, 14(4), 58-65.

Nua Ltd. (2000) Forrester Research: USD7 Trillion in Ecommerce Revenues by 2004, URL http://www.nua.ie/surveys/?f=VS\&art_id=905355736\&rel=true

Parthasarathy, M., \& Bhattacherjee, A. (1998) "Understanding post-adoption behaviour in the context of online services" Information Systems Research, 9(4), 362-379.

Pollatsek, A., \& Tversky, A. (1970) "A theory of risk" J. Math. Psych., 7, 540-553.

Ratnasingham, P. (1999) "Implicit trust in the risk assessment process of EDI" Computers \& Security, 18, 317321.

Rebel, T.F. and Koenig, W. (1999) "Ensuring security and trust in electronic commerce" in Doing Business on the Internet: Opportunities and Pitfalls. edited by Fay Sudweeks and Celia T. Romm. Springer: London, 101-112.

Richtel, M., \& Robinson, S. (2000 9 Feb.) "Several Web Sites Attacked Following Assault on Yahoo" New York Times, P. Al.

Rogers, E.M. (1983) Diffusion of Innovation. The Free Press: New York., Third Edition.

Salancik, G.R., Pfeffer, J. (1978) " A social information processing approach to job attitudes and task design" Administrative Science Quarterly, 23, 224-253.

Schmitz, J., \& Fulk, J. (1991) "Organizational colleagues, media richness, and electronic mail: A test of the social influence model of technology use" Communication Research, 18(4), 487-523.

Schwartz, J. (2000) "Poll: Hack attacks dent e-confidence". Washing Post, 2 March 2000, E08. URL http://washingtonpost.com/wp-dyn/business/A56622-2000Marl.html

Simpson, L., \& Lakner, H.B. (1993) "Perceived risk and mail order shopping for apparel" Journal of Consumer Studies and Home Economics, 17, 377-398.

Straub, D.W., \& Welke R.J. (1998) "Coping with systems risk: Security planning models for management decision making" MIS Quarterly, 22(4), 441-469.

Switzer,P. (2000) "Hype jumps on, survey finds". The Australian, 3 April, 37.

Szajna, B. (1996) "Empirical evaluation of the revised technology acceptance model" Management Science, 42(1), 85-92.

Taylor, S., \& Todd, P.A. (1995) "Assessing IT usage: The role of prior experience" MIS Quarterly, 19(4), 561570.

Thompson, R.L., Higgins, C.A., \& Howell, J.M. (1994) "Influence of experience on personal computer utilization: Testing a conceptual model” Journal of Management Information Systems, 11(1), 167-187.

Till, R. (1998) "Transforming the way we do business". in T. Nash (ed.) Electronic Commerce: Directors and Opportunities for Electronic Business, Director Pub. Ltd.

Venkatesh, V., \& Davis, F.D. (1996) "A model of the antecedents of perceived ease of use: Development and test" Decision Sciences, 27(3), 451-481.

Venkatesh, V., \& Morris, M.G. (2000) "Why don't men ever stop to ask for directions? Gender, social influence, and their role in technology acceptance and usage behaviour" MIS Quarterly, 24(1), forthcoming.

$\mathrm{Vu}, \mathrm{T}$., Smith, P., \& Bennett, T. (1999) BizRate.com, NPD Joint Survey Reveals 75 percent of Online Customers are Abandoning Shopping Cart. bizrate.com press release, URL http://www.bizrate.com/press/press_room/release_49.xpml

Zampetakis, H. (2000) "Digital Ids pave wireless web way" The Australian Financial Review, 8 April, 19. 